Türkiye Mesleki ve Sosyal Bilimler Dergisi, Ağustos 2021, Yıl: 3, Sayı: 6, 10-18. Journal of Vocational and Social Sciences of Turkey, Aug 2020, Year: 3, No: 6, 10-18.

ARAŞTIRMA MAKALESI / RESEARCH ARTICLE

Atıf için /for cited: Sevim, E., Nal, M., Önder, E. (2021). Investigation of Reimbursement Methods in Healthcare Services Through AHP. Journal of Vocational and Social Sciences of Turkey, Yll: 3, Sayl: 6, Ağustos 2021, s.10-18.

\title{
INVESTIGATION OF REIMBURSEMENT METHODS IN HEALTHCARE SERVICES THROUGH AHP
}

\section{Ekrem SEVİM*}

\author{
Mustafa NAL ${ }^{* *}$
}

Emrah ÖNDER ${ }^{* * *}$

\begin{abstract}
The aim of the study is to determine the most appropriate method by examining the reimbursement methods used in health services. Analytic Hierarchy Process (AHP) method, one of the multi-criteria decision making techniques, was used in order to achieve the determined goal. Expert opinions were obtained from academicians and healthcare managers during the evaluation of the methods. The data obtained were analyzed by using the "super decision" package program. As a result of the analysis, Global Budget has been selected as the most appropriate reimbursement method. The factor weight of this method was determined as $24.26 \%$. The "Cost Control" criterion used in determining the reimbursement method was found to be the most important evaluation criterion with a $34.25 \%$ factor weight. Global budget management is the most used reimbursement method in Turkey in recent years. It is thought that this situation affects the results of the study. In addition, it is thought that the method is good in terms of cost control, medium in quality and easy in terms of management is effective in this result.
\end{abstract}

Keywords: Healthcare Services, Reimbursement method, Multi-Criteria Decision Making, AHP.

Jel Code: J10, J18, D70, D73, D81.

\section{SAĞLIK HİZMETLERINNDE GERİ ÖDEME YÖNTEMLERININ AHP İLE İNCELENMESI}

\section{ÖZET}

Çalışmanın amacı sağlık hizmetlerinde kullanılan geri ödeme yöntemlerinin incelenerek en uygun yönteminin belirlenmesidir. Belirlenen amaca ulaşabilmek için çok kriterli karar verme tekniklerinden Analytic Hierarchy Process (AHP) yöntemi kullanılmıştır. Yöntemlerin değerlendirilmesi aşamasında akademisyenlerden ve sağlık yöneticilerinden uzman görüşü alınmıştır. Elde edilen veriler "super decision" paket programı vasıtasıyla analiz edilmiştir. Yapılan analiz sonucunda Global Bütçe, en uygun geri ödeme yöntemi olarak seçilmiştir. Bu yöntemin faktör ağırlığı \%24,26 olarak tespit edilmiştir. Geri ödeme yönteminin belirlenmesinde kullanılan "Maliyet Kontrolü" kriteri ise, \%34,25 faktör ağırlığı ile en önemli değerlendirme kriteri olarak bulunmuştur. Global bütçe yönetimi son yıllarda Türkiye'de en çok kullanılan geri ödeme yöntemidir. Bu durumun, çalışma

Bandırma Onyedi Eylül Üniversitesi, Sağılık Bilimleri Fakültesi, Sağlık Yönetimi Bölümü, Dr.Öğr.Üyesi, esevim@bandirma.edu.tr

** (D) Kütahya Sağlık Bilimleri Üniversitesi, Sağlık Bilimleri Fakültesi, Sağlık Yönetimi Bölümü, Dr.Öğr.Üyesi, mustafa.nal@ksbu.edu.tr

*** (1) Istanbul Üniversitesi, İsletme Fakültesi, İsletme Fakültesi, Prof.Dr., emrah@istanbul.edu.tr 


\section{TÜRKIYE MESLEKI VE SOSYAL BILIMLER DERGISi}

Türkiye Mesleki ve Sosyal Bilimler Dergisi, Ağustos 2021, Yıl: 3, Sayı: 6, 10-18. Journal of Vocational and Social Sciences of Turkey, Aug 2020, Year: 3, No: 6, 10-18.

sonuçlarını etkilediği düşünülmektedir. Ayrıca yöntemin; maliyet kontrolü açısından iyi, kalite açısından orta ve yönetim açısından kolay olmasının bu sonuçta etkili olduğu düşünülmektedir.

Anahtar Kelimeler: Sağlık Hizmetleri, Geri Ödeme Yöntemi, Çok Kriterli Karar Verme, AHP.

Jel Kodu: J10, J18, D70, D73, D81.

\section{INTRODUCTION}

The most important element of a country is the individuals that make up its society. Having a society with a high health level is an indispensable goal for all countries. Moreover, health is among the most fundamental human rights (Şengül \& Bulut, 2019). In addition, the way to reach a society with a high health level is to have a good health system. This goal can be achieved by having a well-structured healthcare system, with its structuring, presentation and financing. One of the most important elements in this structure is the correct design of the reimbursement system that regulates the payments made to service providers (Akyürek, 2012). Reimbursement systems have a direct impact on the attitudes of service providers. Reimbursement organizations want the right patient to receive the right amount of healthcare at affordable costs. Healthcare providers expect quality healthcare to be delivered costeffectively and to generate more revenue. For this reason, it is very important to choose the most suitable reimbursement method.

The reimbursement method used in a health system is critical for the health policy implemented to be successful. The reimbursement methods can also be considered as a kind of resource transfer system. A reimbursement method can be defined as the transfer of the resource allocated for health services from the purchaser to the person or institution involved in the provision of this service and a structure that is combined with the auxiliary systems in this process (Arık \& İleri, 2016; Top \& Tarcan, 2007). Service providers may be health professionals such as physicians or institutionalized centers such as hospitals (Aydemir \& Ağırbaş, 2017). In the study, the reimbursement methods used in health services will be evaluated and the most appropriate method will be selected. In this context, the five most commonly used reimbursement methods were discussed. Cost control, service quality and manageability criteria were used to evaluate these methods.

\section{LITERATURE REVIEW}

\subsection{Reimbursement Methods in Health Services}

The reimbursement method used in terms of the sustainability of health services is very important. Therefore, countries should be very careful when choosing a reimbursement method. In order to maintain quality service delivery, resource allocation must be fair (Işıkçelik vd., 2019). There are generally five different methods within the scope of reimbursement of health services. These methods; Global Budget, Fee For Service, Payment by Day, Diagnosis Related Group (DRG), Capitation Fee. These methods are generally used in combination. These methods are determined in accordance with the development level, democratic, social, political and economic structure of the countries (Kadiz, 2011).

When classifying reimbursement systems in health services, it is an important issue to make payments retrospectively and prospectively. In retrospective payment systems, the cost of the service they have produced is paid to healthcare service providers after the costs are revealed. In prospective payment systems, the amount of payment to be made to the service provider is predetermined (Akyürek, 2012). All of the costs incurred in the retrospective payment system are covered by the healthcare service payers. This situation causes the healthcare providers not to make any effort to reduce the service costs. However, in the prospective reimbursement system, the motivation of healthcare providers to reduce costs creates the risk of not getting the healthcare they need for patients (Jegers vd., 2002). Payment methods determine the relationships between the institutions that provide the financing and produce the service (Belek, 2009). 


\section{TÜRKIYE MESLEKI VE SOSYAL BILIMLER DERGISI}

Türkiye Mesleki ve Sosyal Bilimler Dergisi, Ağustos 2021, Yıl: 3, Sayı: 6, 10-18. Journal of Vocational and Social Sciences of Turkey, Aug 2020, Year: 3, No: 6, 10-18.

Global Budget: It is a system in which a fixed budget is allocated to the health institution in order to cover all its expenditures within a certain period of time. In this method, health institution managers are expected to use the allocated budget efficiently. Additional budget may be requested for unexpected expenses that may occur during the year (Tengilimoğlu vd., 2015:308).

Since it is a prospective form of reimbursement, it may adversely affect the service provision. However, predetermination of costs facilitates manageability. Because of this feature, it is a method generally used in low and middle income countries. Making the payment prospectively causes the amount to be determined in advance. This increases the tendency to reduce service provision (Erdoğan, 2021).

Fee For Service: It is a method in which payment is made for each service offered to the health institution. Payments are made to health institutions at the determined prices for each service provision (Akyürek, 2012; Aydemir \& Ağırbaş, 2017). Payments are made to the health institution for all services such as surgery, bed, analysis and examination (Top \& Tarcan, 2007). It is a retrospective refund system as the payment is made after the service is provided. This situation causes a tendency to increase service provision on service providers. Therefore, the costs are increasing for the reimbursement institution.

This method directs hospitals and hospital staff to produce more healthcare services. In this method, hospitals have no cost concerns. This makes it easier to receive treatment services for patients with complex healthcare needs. In addition, the payment of all services produced encourages the health institution to provide services. In addition, the reimbursement system per service causes unnecessary or excessive service production. This situation emerges as unnecessary exposure for patients and high costs for reimbursement institutions (Erdoğan, 2021).

Payment by Day: It is based on making a payment according to the duration of the service provided to the health institution. The amount of daily payment made according to the number of patients covers applications such as medication and laboratory imaging during the hospitalization (Aydemir \& Ağırbaş, 2017). Costs are calculated annually on the basis of calculating daily costs for a patient. With this calculation, service providers are paid per day. The payment by day method encourages hospitals for higher occupancy rates and more bed capacity (Şantaş \& Çırakl1, 2019).

Diagnosis Related Group (DRG): Reimbursement made according to diagnosis is a method of reimbursement that takes place at a single price or at different rates according to case groups. It is based on categorizing patients who are homogeneous in terms of clinical profile and required resources using demographic, clinical and cost data (Scheller-Kreinsen vd., 2011).

The service produced for healthcare providers is almost fully paid. In addition to providing high satisfaction to service providers, this situation encourages efficient use of resources and lowering costs (Akyürek, 2012). The most negative aspect of this method is that the hospital stay is kept short by the service providers (Akbulut, 2012).

Capitation Fee: It is a model in which all treatment expenses that may be needed are transferred to service providers, whether or not a certain number of people use the services provided in the health institution within a certain period of time. The fact that the payment is fixed and prospectively puts service providers in a financial difficult situation. The positive aspect of the method is that it allows the reimbursement institution to control its costs more easily. This situation leads service providers to limit their costs (Top \& Tarcan, 2007). 


\section{TÜRKIYE MESLEKI VE SOSYAL BILIMLER DERGISI}

Türkiye Mesleki ve Sosyal Bilimler Dergisi, Ağustos 2021, Yıl: 3, Sayı: 6, 10-18. Journal of Vocational and Social Sciences of Turkey, Aug 2020, Year: 3, No: 6, 10-18.

Table 1. Comparison of Performance of Different Reimbursement Systems

\begin{tabular}{|c|c|c|c|}
\hline Payment system & Cost containment & Quality & Administration \\
\hline Global Budget & Good & Fair & Easy \\
\hline Fee For Service & Poor & Good & Difficult \\
\hline Payment by Day & Fair & Poor & Easy \\
\hline Diagnosis Related Group & Good & Fair & Easy \\
\hline Capitation Fee & Good & Fair & \\
\hline
\end{tabular}

Reference: (Normand and Weber 2009:98)

Reimbursement methods can be evaluated according to various criteria. Normand \& Weber (2009: 98) evaluated reimbursement methods according to cost control, service quality and manageability criteria (Table 1). According to this comparison, the global budget method is evaluated as "good" in terms of cost control, "fair" in terms of service quality and "easy" in terms of manageability. According to the same comparison, the payment per service method was evaluated as "poor" in terms of cost control, "good" in terms of service quality and "difficult" in terms of manageability. In this case, it is important to make an assessment by taking these three criteria into account.

\subsection{Analytical Hierarchy Process (AHP)}

The Analytical Hierarchy Process was developed by Thomas L. Saaty in the 1970s with the aim of solving multi-criteria decision making problems (Önder \& Önder, 2014). Analytical Hierarchy Process is one of the selection methods in which more than one decision-maker can be included in the process in decision problems involving many alternatives. At the top of the hierarchy is the real goal of the decision maker. At lower levels, the criteria to be taken into account in order to achieve this goal are listed. At the lowest level of the hierarchy, there are decision alternatives (Görener, 2016).

Table 2. The Fundamental Scale of Absolute Numbers

\begin{tabular}{|c|c|c|}
\hline \begin{tabular}{c|}
$1-9$ \\
Scale
\end{tabular} & Definition & Explanation \\
\hline 1 & Equal Importance (E) & Two activities contribute equally to the objective \\
\hline 2 & Weak (W) & \\
\hline 3 & Moderate Importance $(\mathrm{M})$ & Experience and judgement slightly favour one activity over another \\
\hline 4 & Moderate Plus (M+) & \\
\hline 5 & Strong Importance $(\mathrm{S})$ & Experience and judgement strongly favour one activity over another \\
\hline 6 & Strong Plus $(\mathrm{S}+)$ & \\
\hline 7 & $\begin{array}{l}\text { Very Strong or Demonstrated } \\
\text { Importance (VS) }\end{array}$ & $\begin{array}{l}\text { An activity is favoured very strongly over another; its dominance } \\
\text { demonstrated in practice }\end{array}$ \\
\hline 8 & Very, Very Strong (VVS) & \\
\hline 9 & Extreme Importance (Ex) & $\begin{array}{l}\text { The evidence favouring one activity over another is of the highest } \\
\text { possible order of affirmation }\end{array}$ \\
\hline
\end{tabular}

Reference: (Niemira ve Saaty, 2004)

The evaluation of alternatives with the specified criteria is made through the 1-9 scale developed by Saaty (2008). 1 indicates equal importance, 3 indicates medium importance, 5 indicates strong importance, 7 indicates very strong importance, and 9 indicates extreme importance. Even numbers represent intermediate values (Table 2).

The study is important in terms of evaluating the most commonly used reimbursement methods in health services with AHP, which is one of the multi-criteria decision-making techniques. Cost control, service quality and manageability criteria were used in the evaluation of these methods. In terms of these criteria, the most appropriate reimbursement method will be selected. 


\section{TÜRKIYE MESLEKI VE SOSYAL BILIMLER DERGISI}

Türkiye Mesleki ve Sosyal Bilimler Dergisi, Ağustos 2021, Yıl: 3, Sayı: 6, 10-18. Journal of Vocational and Social Sciences of Turkey, Aug 2020, Year: 3, No: 6, 10-18.

\section{METHODOLOGY}

The aim of the study is to determine the most appropriate method by examining the reimbursement methods used in health services. Analytical Hierarchy Process (AHP) method, one of the multi-criteria decision-making techniques, was used in order to reach the aim of determining the most suitable reimbursement method by examining the reimbursement methods in the study.

In this process, face-to-face interviews were held with a total of 10 experts, five of whom were academics working in the health management departments of universities and who have academic studies on reimbursement methods, and five healthcare managers working in reimbursement units in their institutions within the scope of obtaining expert opinion.

Reimbursement methods constitute alternatives of the problem. Cost control, service quality and manageability criteria were used to evaluate alternatives. The experts consulted, evaluated the determined criteria and alternatives through paired comparison forms prepared using Saaty's 1-9 scale. The views of each expert group were combined among themselves by taking geometric averages, and they were entered into the "super decision" package program as a single data. In this way, reimbursement methods were evaluated among themselves in terms of their suitability within the framework of the determined criteria.

\section{RESULTS}

Reimbursement methods used in health services were examined through three criteria used to evaluate these methods. As a result of the analysis, the "Cost Control" criterion was the most important criterion and its weight was found to be $39.15 \%$. The weight of the "Service Quality" criterion was determined as $34.37 \%$ and the weight of the "Manageability" criterion as $26.49 \%$ (Figure 1).

Figure 1. Criteria Used in the Evaluation

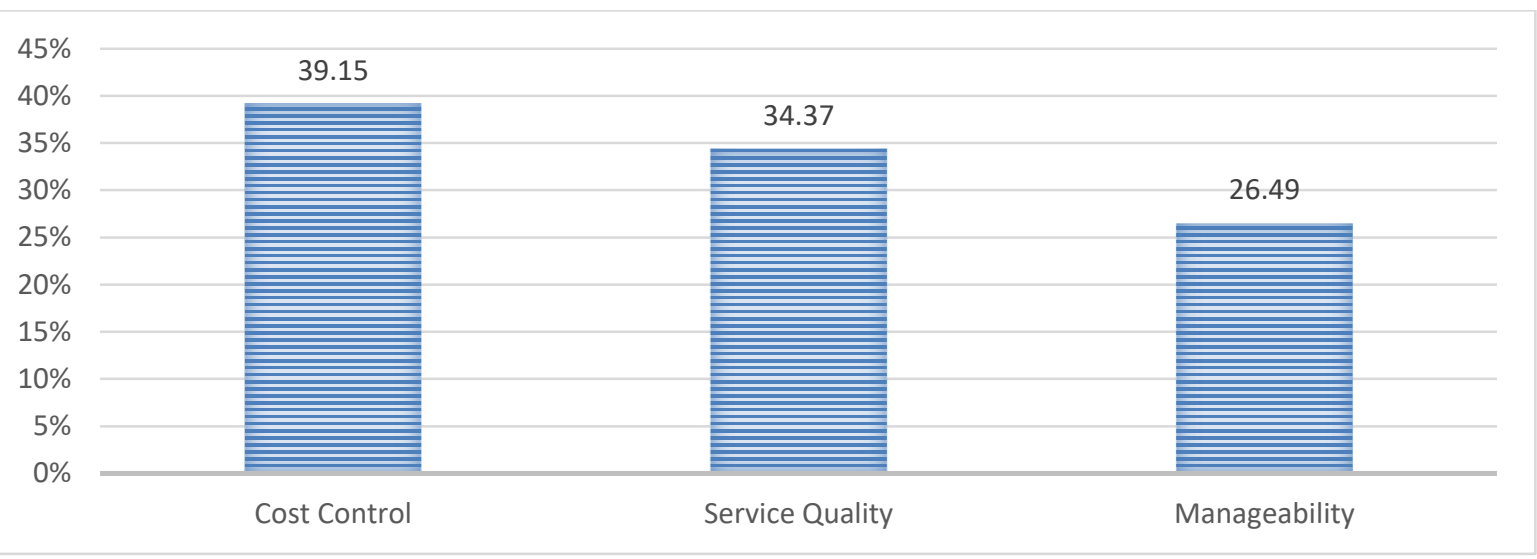

As a result of the analysis, the "Global Budget" method was found to be the most preferrable reimbursement method with $24.26 \%$. This method was followed by "Diagnosis Related Group" (23.33\%), "Capitation Fee" (21.39\%), "Fee For Service" (16.60\%) and "Payment by Day" (14.44\%) (Figure 2). 


\section{TÜRKIYE MESLEKI VE SOSYAL BILIMLER DERGISI}

Türkiye Mesleki ve Sosyal Bilimler Dergisi, Ağustos 2021, Yıl: 3, Sayı: 6, 10-18. Journal of Vocational and Social Sciences of Turkey, Aug 2020, Year: 3, No: 6, 10-18.

Figure 2. Ranking of Reimbursement Methods

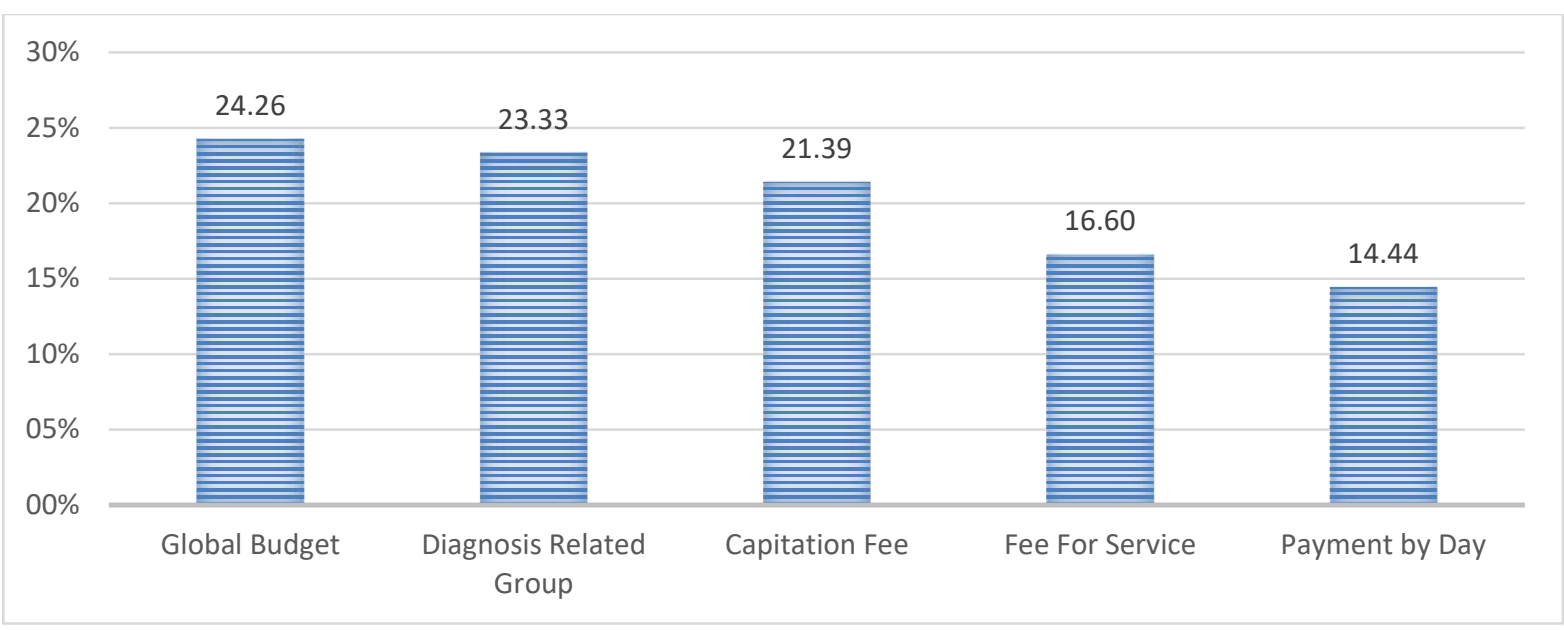

The perspectives of academicians and health managers on reimbursement methods used in health services were examined separately. In terms of academicians, the weight of the "Cost Control" criterion was found to be $32.45 \%$, "Service Quality" 35.15\% and "Manageability" $32.41 \%$. The weight of the "Cost Control" criterion in terms of health managers was found to be $45.69 \%$, quality $19.06 \%$ and manageability $32.25 \%$. While cost management is the most important criterion for health managers, service quality is considered the most important criterion for academics. There are significant differences between the two groups in terms of cost control and service quality. However, the mean scores of the two groups are close to each other in terms of manageability (Figure 3).

Figure 3. Ranking of the Criteria According to Academicians and Health Managers

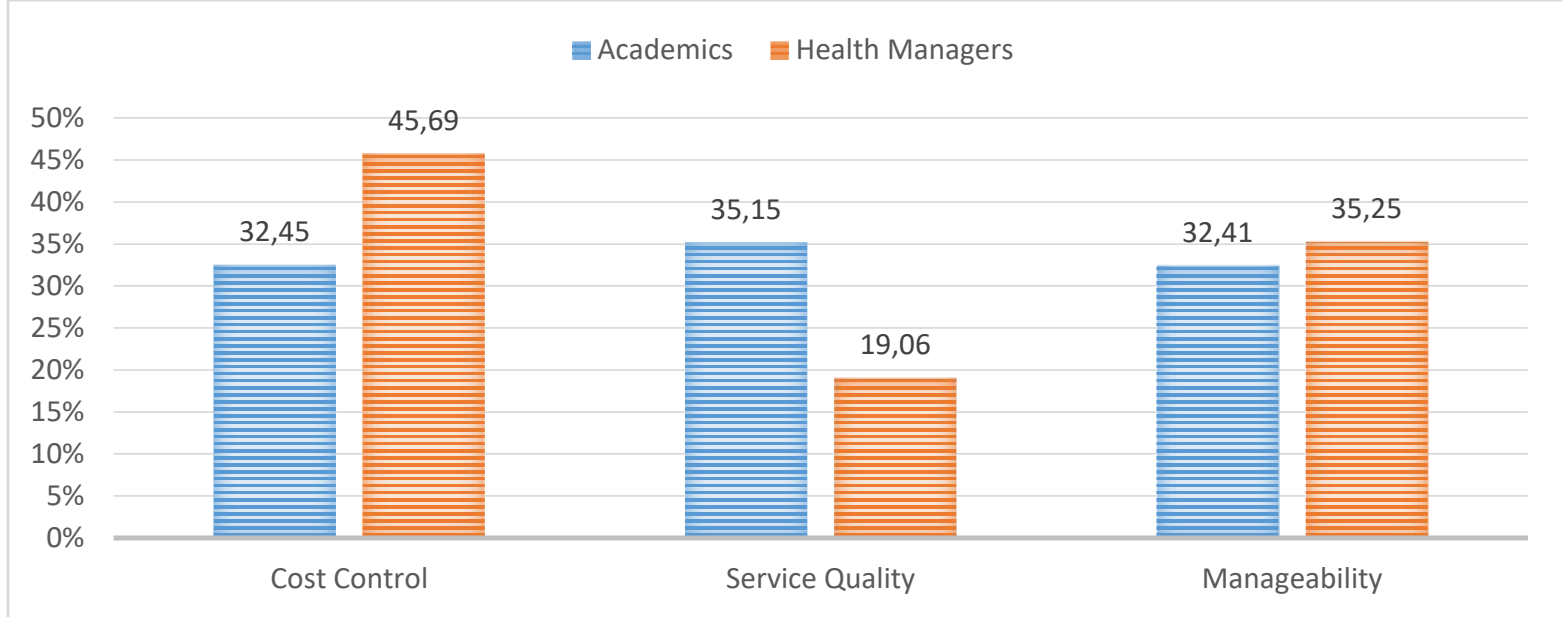

The perspectives of academicians and healthcare managers on reimbursement methods were examined separately. In terms of academicians, the "Global Budget" method is 23.50\%, "Diagnosis Related Group" 27.02\%, "Capitation Fee" 17.72\%, "Fee For Service" 17.99\% and "Payment by Day" 13.77\%, In terms of healthcare managers, the "Global Budget" method is 25.01\%, "Diagnosis Related Group" 19.63\%, "Capitation Fee" 25.06\%, "Fee For Service" 15.20\% and "Payment by Day" 15.11\%. (Figure 4). 


\section{TÜRKIYE MESLEKI VE SOSYAL BILIMLER DERGISI}

Türkiye Mesleki ve Sosyal Bilimler Dergisi, Ağustos 2021, Yıl: 3, Sayı: 6, 10-18. Journal of Vocational and Social Sciences of Turkey, Aug 2020, Year: 3, No: 6, 10-18.

Figure 4. Ranking of Reimbursement Methods According to Academicians and Health Managers

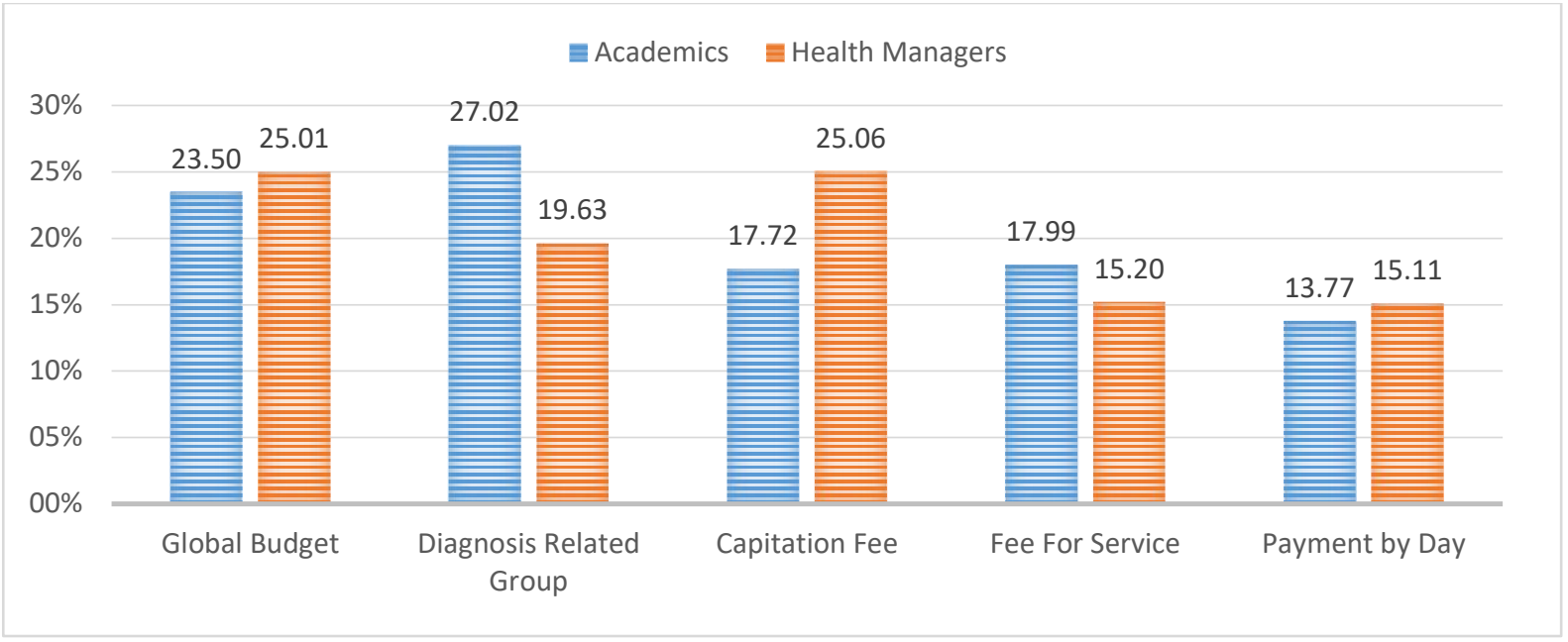

When the findings were examined in general, it was seen that there were different perspectives among the academicians and health managers in terms of both alternative reimbursement methods and the criteria used to evaluate these methods.

\section{CONCLUSION}

The AHP method was used in the study conducted to determine the most appropriate reimbursement method used in health services. In this context, the five most frequently used reimbursement methods were evaluated using cost control, service quality and manageability criteria. According to the results of the study, the cost control criterion was chosen as the most important criterion in evaluating reimbursement methods. Global budget has been preferred as the most suitable reimbursement method. Özkan \& Ağırbaş (2018) stated that the global budget application should cover all public/private healthcare institutions and in addition, it would be beneficial to make the reimbursement according to the DRG method. Normand \& Weber (2009:98) evaluated the payment per service method as good in their study. Choosing the global budget method in the study does not support the work of Normand \& Weber (2009:98). It can be said that the most common repayment method in the country is the global budget method, which is the most important reason for the results of the study to emerge in this way. In addition, it is thought that the method is good in terms of cost control, medium in quality and easy in terms of management is effective in this result.

The difference between the perspectives of academicians and healthcare managers on reimbursement methods is important. While academics look at the issue from an academic perspective, the perspectives of health administrators can be considered more practical. In this context, while the most important criterion for academics is service quality, the most important criterion for health administrators is cost control.

The DRG method was chosen as the most appropriate reimbursement method for academicians. In this method, manageability is difficult and cost control is expressed as good and quality is medium. In addition, academics evaluated that the payment method per day ranks last. In addition to the fact that this method is evaluated as easy in terms of management criteria by Normand \& Weber, (2009:98), it can be thought that it is effective to show the cost criterion as medium and the quality criterion as weak. Because the most important criterion for academicians in the study is the quality criterion.

The per capita payment method has been selected as the most appropriate reimbursement method for healthcare managers. In this method, in addition to being easy to manage, cost control was expressed as good and quality was expressed as medium. In addition, the pay-per-day method has been ranked 


\section{TÜRKIYE MESLEKI VE SOSYAL BILIMLER DERGISi}

Türkiye Mesleki ve Sosyal Bilimler Dergisi, Ağustos 2021, Yıl: 3, Sayı: 6, 10-18. Journal of Vocational and Social Sciences of Turkey, Aug 2020, Year: 3, No: 6, 10-18.

last for healthcare managers. In addition to the fact that this method is evaluated as easy in terms of management criteria by Normand \& Weber, (2009:98), it can be thought that it is effective to show the cost criterion as medium and the quality criterion as weak. Because the most important criterion for health managers in the study is the cost control criterion.

In the study conducted by Erdoğan (2021), Health Practice Notification and DRG methods were compared in terms of reimbursement rates. There was no clear superiority between the two methods. It has been stated that the methods used have not only the desired effects but also undesirable effects. In our study results, it can be said that different methods stand out from different angles.

In the study conducted by Aydemir \& Ağırbaş (2017), it has been stated that reimbursements made to service providers with DRG are important in terms of preventing the victims of service providers in terms of costs. In the study, DRG was chosen as the most appropriate reimbursement method, especially by academics. The results of the two studies are similar in this respect.

In the study conducted by Akyürek (2012), the global budget method was discussed. It is stated as an advantage that the method provides convenience to governments in terms of cost control. In the study, the global budget method was chosen as the most appropriate reimbursement method. It can be evaluated that the results of the study are similar in this respect.

When countries are choosing a reimbursement method in health services, it may be recommended to use different methods in an integrated manner, rather than a single reimbursement method. Thus, it is ensured to benefit from the advantages of different methods. The study can be repeated with different expert groups and methods.

\section{KAYNAKÇA}

Akbulut, Y. (2012). "Sağlık Sigortacılığında Ödeme Yöntemleri”. İçinde Hasan Hüseyin Yıldırım (Ed.), Sağlık Sigortacılığı, Eskişehir: Anadolu Üniversitesi AÖF Yayımları.

Akyürek, Ç. E. (2012). "Sağlıkta Bir Geri Ödeme Yöntemi Olarak Global Bütçe ve Türkiye", Hacettepe Sağlık İdaresi Dergisi, 2(2).

Arık, Ö. \& İleri, Y. Y. (2016). "Sağlık Hizmetlerinin Finansmanında Türkiye'de Yeni Yaklaşım; Teşhis İlişkili Gruplar (TİG)", SDÜ Sağlık Bilimleri Enstitüsü Dergisi, 7(2), 45-50. https://dergipark.org.tr/en/download/article-file/222225

Aydemir, İ. \& Ağırbaş, İ. (2017). "Sağlık Kurumlarına Yapılan Geri Ödeme Yöntemleri: Teşhis İlişkili Gruplar", Hacettepe Sağlık İdaresi Dergisi, 20(1), 1-21.

Belek, İ. (2009). Sağlığın Politik Ekonomisi, Sosyal Devletin Çöküşü, İstanbul: Yazılama Yayınları.

Erdoğan, P. (2021). "Sağlık Kurumlarına Yapılan Geri Ödeme Yöntemleri: SUT-TíG Karşılaştırmassı", Hacettepe Sağlık İdaresi Dergisi, 24(1), 15-28. https://dergipark.org.tr/en/download/article-file/1659704

Görener, A. (2016). "A SWOT-AHP Approach for Assessment of Medical Tourism Sector in Turkey", Alphanumeric Journal, 4(2), 159-159. https://doi.org/10.17093/alphanumeric.277740

Işıkçelik, F., Öztürk, N. \& Ağırbaş, İ. (2019). "Sağlık Hizmetlerinde Geri Ödeme Yöntemlerinden Teşhis İlişkili Gruplar", Sosyal Güvenlik Dergisi, 9(2), 431-448. https://doi.org/10.32331/sgd.658891

Jegers, M., Kesteloot, K., De Graeve, D. \& Gilles, W. (2002). "A Typology for Provider Payment Systems in Health Care", Health Policy, 60(3), 255-273. https://doi.org/10.1016/S0168-8510(01)00216-0

Kadız, Y. (2011). DRG ile Geri Ödeme Sistemi ve Hastane Yöneticilerinin Bu Sisteme İlişkin Tutumları, Yüksek Lisans Tezi, Dokuz Eylül Üniversitesi.

Niemira, M. P. \& Saaty, T. L. (2004). "An Analytic Network Process Model for Financial-Crisis Forecasting", International Journal of Forecasting, 20(4), 573-587. https://doi.org/10.1016/j.ijforecast.2003.09.013

Normand, C. \& Weber, A. (2009). Social Health Insurance: A Guidebook for Planning. In World Health. http://libdoc.who.int/publications/50786.pdf

Önder, G. \& Önder, E. (2014). "Analitik Hiyerarşi Süreci" B.F. Yıldırım, E. Önder (Ed.), Operasyonel, Yönetsel ve Stratejik Problemlerin Çözümünde Çok Kriterli karar Verme Yöntemleri, içinde (21-74), Bursa: Dora Basım-Yayın Dağıtım.

Özkan, O. \& Ağırbaş, İ. (2018). "Sağlık Bakanlığı Global Bütçesinin Teşhis İlişkili Gruplara Göre Dağıtımı", Ankara Üniversitesi Tıp Fakültesi Mecmuas1, 71(3), 163-171. DOI: 10.4274/atfm.27136.

Scheller-Kreinsen, D., Quentin, W. \& Busse, R., (2011). "DRG-Based Hospital Payment Systems and 


\section{TÜRKIYE MESLEKI VE SOSYAL BILIMLER DERGISI}

Türkiye Mesleki ve Sosyal Bilimler Dergisi, Ağustos 2021, Yıl: 3, Sayı: 6, 10-18. Journal of Vocational and Social Sciences of Turkey, Aug 2020, Year: 3, No: 6, 10-18.

Technological Innovation in12 European Countries", Value in Health, 14(8), 1166-1172.

Şantaş, F., \& Çıraklı, Ü. (2019). "Sağlık Hizmetlerinin Finansman ve Geri Ödenme Yöntemleri: Türkiye’de Mevcut Durum", Uluslararası Sağlık Yönetimi ve Stratejileri Araştırma Dergisi, 5(1), 12-20.

Şengül, H., \& Bulut, A. (2019). "Sağlık Hizmetlerinde Ödeme Mekanizmaları ve Teşhis ile İlişkili Gruplar", ESTÜDAM Halk Sağlığı Dergisi, 4(2), 196-209.

Tengilimoğlu, D. \& Işık, O. ve Akbolat, M. (2015). Sağlık İşletmeleri Yönetimi, Ankara: Nobel Akademik Yayıncilik.

Top, M. \& Tarcan, M. (2007). "Hastane Sektöründe Kaynak Akışı: Hastane Ödeme Yöntemleri (Mekanizmaları)", Gazi Üniversitesi İktisadi ve İdari Bilimler Fakültesi Dergisi, 9(1), 169-189. 